\title{
ACRL Strategic Plan
}

\section{Support ACRL's plan with your activities}

$\mathbf{T}$ his is a time of great opportunity and challenge for librarians, mediated by changes in the nature of access to information. Never before have librarians and libraries been perceived as being so central to the teaching and learning process. To position ACRL and empower academic librarians for the 21st century, the ACRL Strategic Plan was adopted by the ACRL Board of Directors in 1995 following extensive input and comments from the membership

The Strategic Plan is a dynamic document that provides a framework for the division's decision-making. Because ACRL operates within the rapidly evolving higher education and academic library environments, it is important that the Strategic Plan enable us to respond positively and quickly, and in order to do so we will need to change it periodically.

The strategic directions outlined in the plan will be reviewed for changes on an annual basis. ACRL members are encouraged to bring their recommendations for changes in writing to the Board at the Midwinter Meeting or the spring Executive Committee meeting. The Board of Directors will consider recommended changes at the annual conference that follows those meetings.

During the 1996 ALA Annual Conference in New York the Board of Directors approved one change to the Strategic Plan. Under Goal 1, a new strategic direction (\#1.5) was added upon recommendation from the Publications Committee.

I urge you to read the plan and help your unit focus its activities on one or more of the four goals.-William Miller, ACRL President

\section{Mission}

The Association of College and Research Libraries (ACRL) provides leadership for development, promotion, and improvement of aca- demic and research library resources and services to facilitate learning, research, and the scholarly communication process.

ACRL promotes the highest level of professional excellence for librarians and library personnel in order to serve the users of academic and research libraries.

\section{Vision}

Together, ACRL members will strengthen the ability of academic and research librarians and other library personnel to provide superior services and resources for their communities; and will prepare academic and research librarians to play increasingly significant roles in higher education. ACRL will provide leadership in shaping education, information, and scholarly communication policy. It will achieve this through partnerships with higher education and information technology organizations, national forums, and through the legislative process. ACRL will recruit and foster the retention of highly qualified and talented librarians who reflect the diversity found in American society. ACRL will develop standards for professional preparation and promote continuous learning for academic and research librarians and other library personnel.

\section{Goals}

1. Provide development opportunities for academic and research librarians and other library personnel that enhance their ability to deliver superior services and resources.

\section{Strategic Directions:}

1.1 ACRL will support activities which provide opportunities for academic and research librarians and library personnel to discuss and share ideas, knowledge, research, experiences, and expertise.

1.2 ACRL will support recruitment efforts to bring into the profession those individuals who will enrich the diversity of the profession.

1.3 ACRL will provide national programming at the regional level to support continuing education needs. 
1.4 ACRL will continue to seek ways to increase membership participation in its activities.

1.5 ACRL will promote study, research, and publications relevant to academic and research librarianship.

\section{Collaborate with other professional or-} ganizations and associations of higher education in order to promote mutual interests.

Strategic Directions:

2.1 ACRL will participate in activities of, and seek cooperative relationships with, higher education associations.

2.2 ACRL will seek cooperative relationships with other information-related associations to develop cooperative initiatives to enhance and expand the library's role as central to academic endeavors.

2.3 ACRL will strengthen its relationship with the Association of Research Libraries.

2.4 ACRL will work with higher education and scholarly associations to protect access to intellectual property in an electronic environment.

3. Maintain at the national level a prominent role in planning and decision making for influencing information policy. Strategic Directions:

3.1 ACRL will provide financial support for the ALA Goal 2000 technology initiative and legislative agenda to insure that the items of concern to academic librarians receive prompt attention.

3.2 ACRL will support the ALA Washington Office in responding to issues affecting academic libraries and higher education.

3.3 ACRL will use an effective communication mix to promote an understanding of the value and contributions of academic/research librarians and libraries to higher education and society in general.

3.4 ACRL will participate in activities of higher education and other organizations to inform these groups of the value of library resources and services and the library's role in the teaching/learning and scholarly process.

4. Ensure that ACRL's operating environment provides efficiency in its use of resources and effectiveness in the delivery of services to its members and constituent units.

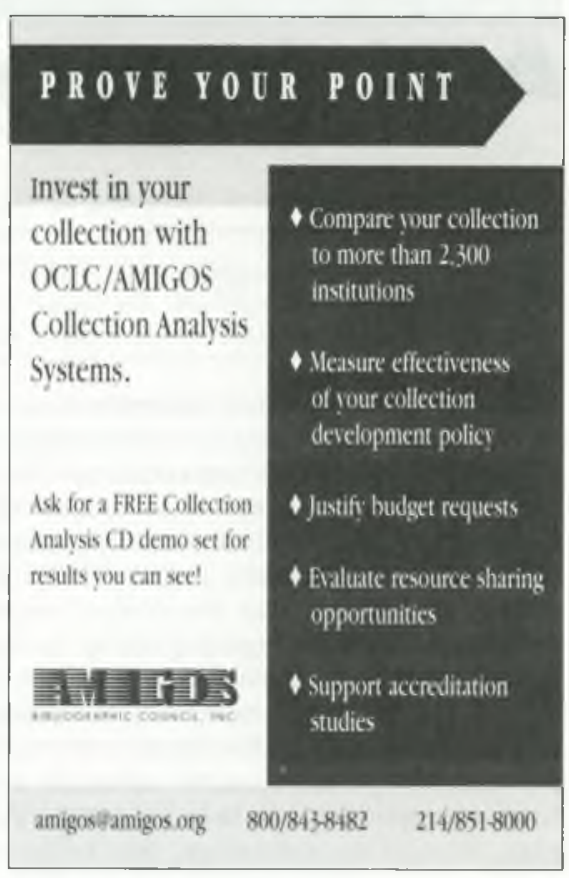

\section{Strategic Directions:}

4.1 The ACRL Board of Directors will take responsibility for planning in order to provide organizational direction.

4.2 ACRL will develop and maintain an in tegrated dynamic management system and process that include: a strategic plan, a financial plan, and product-line marketing or business plans.

4.3 Members of the ACRL Board of Directors will act with the mission, vision, and goals of the association in mind, and ensure that issues and ideas are examined and discussed openly and thoroughly with the membership.

4.4 ACRL will examine and modify as appropriate its current structural arrangements to enhance its influence on information policy setting and legislation through better coordination of national and state efforts.

4.5 ACRL will review and revise its bylaws to reflect the roles of the Board of Directors and all ACRL units.

4.6 ACRL will keep informed of current association management practices and appropriate technologies to ensure that it operates at an optimum level of efficiency. 